\title{
The Geopolitical Origins of Turkish-American Relations: Revisiting the Cold War Years
}

\author{
Ayşe Ömür Atmaca \\ Hacettepe University
}

\begin{abstract}
Critical geopolitics provides ways of looking at the world and questioning the role of geopolitics in foreign policymaking processes, as opposed to accepting them as objective and natural. From this theoretical perspective, this article aims to apply critical geopolitics to the case of Turkish-American relations with respect to how the United States (US) viewed Turkey's geography and how the Turkey-US alliance has been shaped by the foreign and security policies of the latter. The article argues that the alliance was a product of the US' Cold War geopolitical discourse, wherein the US considered Turkey to be a strategic ally against Soviet expansion. Thereafter, the declaration of the Truman Doctrine on March 12, 1947, led to increased US military ties with Turkey and became the basis for Turkey's inclusion in NATO in 1952. As a consequence, Turkey began to be defined as the anchor of NATO's strategic southern flank and a barrier against the communist threat in the Middle East and the Mediterranean throughout the Cold War. Turkey has also been a major recipient of American military equipment and was a supplier of important military facilities for monitoring the Soviet Union. The paper also argues that while Turkey generally fits within the US'geopolitical designs and that these two countries cooperated on numerous efforts during the Cold War, the Cyprus problem in that period revealed the limits of US geopolitical discourse.
\end{abstract}

Keywords: US Foreign Policy, Cold War, Turkish-American relations, geopolitical discourse, critical geopolitics

\section{Introduction}

Critical geopolitics examines the geopolitical imagination of the state. The main premise of this theory is described as "the contention that geography and historical discourse [are] always intimately bound up with questions of politics and ideology." "1 Thus, the Cold War geopolitical narrative, while proposing different political and economic models, also offered different 'imaginations,' made possible by the language of 'blocs,' 'containment,' and 'dominoes.' Ó Tuathail and Agnew assert that '[t] he simple story of a great struggle between a democratic 'West' against a formidable and expansionist 'East' became 'the most influential and durable geopolitical script of [the Cold War] period."'2

Critical geopolitics also demonstrates how places were defined as a 'threat' or as 'strategically important,' and how these definitions have changed over time. Within this

\footnotetext{
Ayşe Ömür Atmaca, Dr. Department of International Relations, Hacettepe University. Email: atmaca.omur@gmail.com.

1 Michel Foucault, cited in Gearóid Ó Tuathail and John Agnew (eds.), A Companion to Political Geography (Washington: Blackwell, 1998), 79.

2 Gearóid Ó Tuathail and John Agnew, "Geopolitics and Discourse: Practical Geopolitical Reasoning in American Foreign Policy," Political Geography 11 (1992): 190.
} 
framework, this study outlines the roots of Turkish-American relations and Turkey's geopolitical position in US foreign policy during the Cold War. It also aims to understand the basis of this relationship and the factors affecting it.

It has been said that the US' primary interest in Turkey during the Cold War was its geopolitical location. Because of Turkey's proximity to the Soviet Union and its historical ties with the Middle East, the US saw benefits in improving its relations with Turkey. Under the Cold War conditions, the US created a geopolitical discourse that shaped its foreign policy and aimed to prevent Soviet expansion into the Middle East and eastern Mediterranean. Turkey's geographical position suited this policy of containment: the US perceived Turkey as a barrier against the Soviet Union, a guardian of NATO's southern flank, and an important military base in the Middle East and eastern Mediterranean.

To understand the relationship between Turkey and the US in the post-Cold War period, it is necessary to know why the two countries established and maintained their alliance in spite of internal and international crises that could have easily discouraged and severed such ties. In this paper, the relationship is studied within the context of critical geopolitics, which shows how geopolitical discourse shapes, and in turn is shaped by, foreign policymaking.

\section{The Political Dimension of Turkey-US Relations}

\subsection{The Turkish Straits question and the beginning of relations}

When the Ottoman Empire attracted the attention of the great powers in the late nineteenth century, there was no geopolitical relationship between the US and the Ottoman Empire. In fact, the most important issues bringing the US and Turkey together were the post-World War II environment and the Soviet Union's territorial demands on Turkey. The question of the Turkish Straits can be taken as one of the first geopolitical crises of the Cold War era. Indeed, the issue existed between Turkey and the Soviet Union before World War II; rules about passage through the Straits had been determined by the Lausanne Treaty in 1923. As a response to the Turkish government's demands for revising these rules, on July 20, 1936 the Montreux Convention on the Regime of the Turkish Straits was signed. ${ }^{3}$ Accordingly, the international regime of passage rights was abolished and Turkish military control over the Straits was established. This new regime added valuable assets to the Turkish geopolitical image.

However, World War II changed the international environment, and the Turkish Straits became more crucial for the Soviet Union. In September 1939, Turkish Foreign Minister Saraçoğlu visited Moscow to sign a mutual aid pact with the Soviet Union. ${ }^{4}$ Soviet officials asked for mutual defense of the Straits, which would give them the opportunity to control strategic bottlenecks, but the Turkish government refused. After the war, Stalin reiterated this request at the Yalta Conference (February 1945), and Britain and the US agreed in principle. ${ }^{5}$ When Turkey demand a renewal of the 1925 Treaty of Neutrality and Non-Aggression, the Soviet Union responded on March 19, 1945 that this demand would be met only if Turkey agreed to the joint defense of the Straits. ${ }^{6}$ On June 7, the Soviet Union increased the pressure, demanding Turkey's Kars and Ardahan provinces (a historically contested region), as well as

Baskın Oran (ed.), Türk Dış Politikası: Kurtuluş Savaşından Bugüne Olgular, Belgeler, Yorumlar, Cilt 1: 1919-1980 (Ankara: İletişim, 2001), 90.

Haluk Ülman, Türk-Amerikan Diplomatik Münasebetleri: 1939-1947 (Ankara: Sevinç, 1961), 25-27.

Ibid., 51.

6 Kamuran Gürün, Türk-Sovyet Iliş̧kileri: 1920-1953 (Ankara: Türk Tarih Kurumu Basımevi, 1991), 276-277. 
a base on the Straits. ${ }^{7}$ Stalin raised the question again with Britain and the US at the Potsdam Conference in July 1945. At that time, President Truman described Turkish defense of the Straits as a "selfish control of the waterways of Europe" and "one of the persistent causes of wars in Europe in the last two centuries."

In November 1945, the US Department of State informed the Turkish government of its proposed revisions to the Montreux Treaty. ${ }^{9}$ Britain perceived these demands as a serious threat to British interests in the Middle East, but due to economic difficulties, it needed US support to challenge the Soviet threat. At the Moscow Conference in December 1945, British Foreign Secretary Bevin asserted that "His Majesty's Government could not be indifferent to a Russian threat to Turkey and would stand by her. We could not agree to the Soviet request for a base in the Straits and for the return of Kars and Ardahan." 10 Secretary of State Byrnes supported this idea and the US backed the British position thereafter. Indeed, the main US aim was to prevent Soviet expansion into the Middle East, where oil was the most important strategic concern. Within this framework, Turkey's geopolitical position became vital for containing the ideological and territorial expansion of the Soviet Union.

The above assessment by the US administration established the strategic and ideological borders of the Cold War in the region. According to Edwin C. Wilson, the American ambassador in Ankara at the time, the Russians' real purpose was to dominate Turkey and the eastern Mediterranean. ${ }^{11}$ The main reasoning for this argument was similar to that of the domino theory: If the Soviet Union were strengthened by access to the eastern Mediterranean, the American and British positions would be weakened, and western Europe's vital oil supplies would be jeopardized. It can be argued that Soviet demands justified the US' perception of the strategic importance of the Turkish Straits. In December 1945, US Undersecretary of State Dean Acheson privately guaranteed the Turkish government that the US would support Turkey in resisting Soviet demands, ${ }^{12}$ and Turkey thus refused the renewed Soviet proposal of July 1946.

The US battleship Missouri arrived in İstanbul on April 5, 1946, ostensibly to return the body of Turkish Ambassador Mehmet Münir Ertegün, who had died in Washington in November 1944, to his home country. ${ }^{13}$ In fact, the US sent the battleship to show that it would not allow the Soviet Union to expand into the Middle East and eastern Mediterranean, and that it would support Turkey as a barrier against Soviet expansion.

The Soviet Union sent a note to Turkey on August 7, 1946, repeating its demands regarding the Straits. ${ }^{14}$ On August 19, the US replied that Turkey should continue to be primarily responsible for the defense of the Straits. ${ }^{15}$ The British administration sent a similar response

\footnotetext{
7 Kamuran Gürün, Türk-Sovyet İlişkileri, 283.

8 Quoted in Harry Howard, "Some Recent Developments in the Problem of the Turkish Straits, 1945-1946," Department of State Bulletin 395 (January 26, 1947), 143.

Fahir Armaoğlu, "Boğazlar Konusunda Amerika'nın Türkiye'ye 2 Kasım Notası," in Belgelerle Türk-Amerikan Münasebetleri (Ankara: Türk Tarih Kurumu Basımevi, 1991), 141-142.

10 "Position on Question of the Turkish Straits-Exchange of Notes Between the Soviet Chargé d'affaires and Acting Secretary Acheson," Department of State Bulletin 374 (September 1, 1946), 421.

11 Edwin C. Wilson, İstanbul Press Reactions March 14 to Truman Speech, Ankara, March 14, 1947.

12 Melvyn P. Leffler, "Negotiating from Strength: Acheson, the Russians, and American Power," in Dean Acheson and the Making of U.S. Foreign Policy, ed. Douglas Brinkley (London: Macmillan, 1993), 177.

13 Oran, Türk Dış Politikası, 525.

14 Cemil Bilsel, "The Turkish Straits in the Light of Recent Turkish-Soviet Russian Correspondence," The American Journal of International Law 41 (1947): 739.

15 "Position on Question of the Turkish Straits," 421.
} 
to the Soviet Union on August 21, 1946. ${ }^{16}$ The Missouri's visit and the American answer to the Soviet note can be taken as signs of the US' new geopolitical interests in Turkey and the Near East. ${ }^{17}$ The exchange of notes ended without revision to the Montreux Convention.

On August 23, a memorandum was prepared by US State Department Assistant Chief of Near Eastern Affairs John D. Jernegan, and approved by Secretary Byrnes and Undersecretary Acheson on October 21, 1946, ${ }^{18}$ which asserted that the Soviet Union aimed to weaken Turkey in order to dominate it and use it both as a defense against possible outside attack from the Mediterranean and as a tool for political and military expansion into the Mediterranean and the Middle East. Turkey's position in the Cold War became more apparent in this memorandum. Accordingly, Turkey's key location in the Middle East and its decision to resist Soviet pressure (with the backing of the US and Britain) would become an important example to all Middle East countries. In a potential war, Turkey would be perceived as a natural barrier against an advance by the Soviet Union into the eastern Mediterranean and the Middle East. ${ }^{19}$

\subsection{The Truman Doctrine}

As noted, during the Cold War years, Turkey's geopolitical location was regarded important for Soviet containment. Indeed, control of the Straits was the raison d'être of American strategic policies in the region. At that time, President Harry Truman heeded George Kennan's warnings in the "Long Telegram," ${ }^{20}$ which argued that the US should follow a policy of "containment" to stop Soviet expansion.

In this framework, the first concrete proof of American interest in Turkey can be found in Acheson's statements, providing a private guarantee to Turkey that Soviet territorial demands extended into "spheres of world peace and security" in which the US took the "deepest interest." ${ }^{21}$ Similarly, Loy Henderson, Director of the State Department's Near East and African Affairs, considered Turkey "the most important military factor in the eastern Mediterranean and Middle East" and added that "by its geographical position, Turkey constitutes the stopper in the neck of the bottle through which Soviet political and military influence could most effectively flow into the eastern Mediterranean and Middle East." 22 Acheson also pointed out that "the West had to keep Greece and Turkey out of Soviet hands - or be prepared to accept the subsequent loss of the strategic bases, lines of communication and resources of the Middle East." ${ }^{23}$ These remarks can be accepted as the initial signs of Turkey's position in the new American geopolitical discourse.

Then, on February 21, 1947, the British government declared it was withdrawing its soldiers from Greece and ending its military and economic aid to Greece and Turkey. ${ }^{24}$ The US administration stressed in Congress that without US support, Greece would be taken over by communists and Turkey would find itself in a weak position in the region, and the eastern

"Department of State Bulletin,” US Department of State 16 (January-March 1947).

Şühnaz Yılmaz, "Challenging the Stereotypes: Turkish-American Relations in the Inter-War Era," Middle Eastern Studies 42 (2006): 230.

18 US Department of State, FRUS: The Near East and Africa, 1946 vol. VII (Washington, D.C.: USGPO, 1946), 894.

19 Ibid., 895.

20 US Department of State, FRUS: Eastern Europe: the Soviet Union, vol. VI (Washington, D.C.: USGPO, 1946), 696-709.

21 Leffler, "Negotiating from Strength," 177.

22 US Department of State, FRUS: The Near East and Africa, $1946 \mathrm{vol}$. VII (Washington, D.C.: USGPO, 1946)

23 "Statement by Acting Secretary Acheson," Department of State Bulletin 409-A (May 4, 1947): 847-52.

24 Robert J. Donovan, Conflict and Crisis: The Presidency of Harry S Truman, 1945-48 (New York: Norton \& Company, 1977), 279-291. 
Mediterranean and the Near East would fall under Soviet domination. ${ }^{25}$ On March 12, 1947, President Harry Truman came before Congress and made one of the most important speeches of the post-war era, requesting authorization to extend military and economic assistance to Greece and Turkey. ${ }^{26}$ This speech is considered to be the first important announcement in the US Cold War geopolitical discourse and is thus taken as the official declaration of the Cold War.

Briefly, it can be argued that the Truman Doctrine was a product of the American geostrategic and geopolitical perceptions of Greece and Turkey as key nation-states in the context of security in the Middle East, and crucial to the protection of American national interests in the Mediterranean region. It codified the differences between the US and the Soviet Union; like a classical geopolitician, Truman used the simple and abstract categories of "the free world" and "the enslaved world," which is black-and-white reasoning. His geopolitical understanding divided the world into two camps, good versus evil, capitalism versus communism, the West versus the East, and the US versus the Soviet Union.

For Truman, Greece and Turkey had become crucial because "the failure of the West to prevent a communist takeover in Greece would not only put the Russians on a particularly dangerous flank for the Turks, but strengthen the Soviet Union's ability to cut off allied supplies and assistance in the event of war." ${ }^{27}$ It can be argued that the threat of a regional domino effect influenced the US' decision.

The Truman Doctrine can be taken as one of the most important steps of the US Cold War containment policy, and it was put into effect through economic restoration of Western Europe via the Marshall Plan, and military containment facilitated by the establishment of NATO in 1949. Thus, after President Truman's speech before Congress, geopolitical discourse on the US began to be institutionalized, and these efforts helped justify US interventions throughout the world. The document, called the National Security Council Resolution (NSC)-68 and published in 1950, is one of the key documents outlining the US' Cold War geopolitical discourse. ${ }^{28}$

Resolution-68 outlines the goals of world leadership in the face of the geopolitical challenge of the Soviet Union and communism. The document asserts that "[t]he assault on free institutions is world-wide now, and in the context of the present polarization of power a defeat of free institutions anywhere is a defeat everywhere." ${ }^{29}$ The geopolitical implication of this statement is that all parts of the world have equal strategic importance, and thus a world leader would have to assert authority in all countries. The Soviet system was perceived as incompatible with the US system, and an obstacle to the establishment of 'order' in the international system. The geopolitical role of the US as world leader was clarified in the document as follows: "Our overall policy at the present time may be described as one designed to foster a world environment in which the American system can survive and flourish. It therefore rejects the concept of isolation and affirms the necessity of our positive participation in the world community." ${ }^{30}$ Accordingly, this American system would need to

\footnotetext{
25 Joseph M. Jones, The Fifteen Weeks: February 11-June 5, 1947 (New York: The Viking Press, 1955$), 5$.

26 Harry Truman, "The Truman Doctrine, Public Papers of the Presidents of the United States," in The Geopolitics Reader, eds. Gearóid Ó Tuathail et.al. (London: Routledge, 1998), 58.

27 Ibid., 59.

28 Alan P. Dobson and Steve Marsh, US Foreign Policy since 1945 (New York: Routlegde, 2001), 3.

29 US Department of State, FRUS: National Security Affairs; Foreign Economic Policy, 1950 vol. I (Washington, D.C.: USGPO, 1950), section IV, A.

30 Ibid.
} 
establish global geopolitical rules. Here, its main enemy was defined as the Soviet Union, and its allies were described as the countries advocating "free institutions."

The triple policies of the Truman Doctrine, the Marshall Plan, and document NSC-68 led to billions in economic and military aid for Western Europe, and for Greece and Turkey. With these policies the US administration showed the world that it took over Britain's role in the Middle East and the eastern Mediterranean. Greece's and Turkey's military roles in the Marshall Plan and later in NATO were the key factors in the balance of power of the geostrategic system.

\subsection{The Korean War and NATO}

On April 4, 1949, the North Atlantic Treaty was signed and NATO was established. It was perceived as an institution of the Cold War's geopolitical order. Turkey applied for membership in NATO in May 1950, but was rejected, ${ }^{31}$ mainly because of its location in the geopolitical imaginations of the US and Britain. For them, "Turkey did not belong either to Western Europe or the Atlantic and consequently she could not join the Atlantic regional group." 32

However, as Altunışık and Tür underline, while the US military was not willing to enlarge its institutional commitments in the Mediterranean region, the State Department was concerned about a possible Turkish-Soviet rapprochement as a result of Turkey's exclusion from NATO ${ }^{33}$ the acceptance of Turkey into NATO was linked to Greece's acceptance because of political and geographical considerations. A US State Department report of June $13,1949$ asserted that "[ $\mathrm{t}]$ he loss of Turkey would critically affect US security interests in the Eastern Mediterranean and the Middle East." ${ }^{34}$ The memorandum notes that "[i]t would be unrealistic to include Turkey if Greece were not included." ${ }^{35}$

In the wake of Turkey's rejection by the US and Great Britain for membership in NATO, Turkish policymakers increasingly began to emphasize Turkey's geopolitical importance vis-à-vis the Soviet Union and express concerns about the country's security. These early attempts at reversing the decision had no effect on the Americans and the British, but Turkey got a second chance at NATO membership when the Korean War broke out on June 25, 1950. Turkey re-applied for NATO on August 11, 1950, ${ }^{36}$ and to pad its application sent 4,500 troops to Korea on October 18, 1950.37

After the Korean War, it became clear that the Western Bloc would need Greece and Turkey in the event of a war with the Eastern Bloc. At the North Atlantic Council's meeting in September 1951, Acheson informed the Europeans that Turkish and Greek memberships would be the best way to strengthen the alliance. ${ }^{38}$ Finally, despite opposition from Britain and the Scandinavian states, and thanks to the positive reputation Turkish troops earned

\footnotetext{
31 Melvyn P. Leffler, "Strategy, Diplomacy, and the Cold War: The United States, Turkey, and NATO, 1945-1952," The Journal of American History 71 (1985): 807-825.

32 George McGhee, The US-Turkish-NATO Middle East Connection: How the Truman Doctrine and Turkey's NATO Entry Contained the Soviets (Houndmills, Basingstoke, Hampshire: Macmillan, 1990), 87.

33 Meliha Altunışık and Özlem Tür, Turkey: Challenges of Continuity and Change (New York: Routledge Curson, 2005$), 104$. 38.

34 US Department of State, FRUS: The Near East, South Asia, and Africa, 1949, vol. VI (Washington, D.C.: USGPO, 1949),

35 Ibid., 39.

36 Mehmet Gönlübol, "NATO and Turkey, An Overall Appraisal," The Turkish Yearbook Of International Relations 11 (1971): 25 .

George S. Harris, Troubled Alliance; Turkish-American Problems in Historical Perspective, 1945-1971 (Washington: American Enterprise Institute for Public Policy Research, 1972), 39-40.

38 NATO, "Final Communiqué," accessed April 1, 2010, http://www.nato.int/docu/comm/49-95/c510920a.htm.
} 
in the Korean War, along with the change in American attitudes toward Turkey's strategic importance after 1951, Turkey became a member of NATO on February 18, 1952. ${ }^{39}$ For the US administration, Turkey's geopolitical role in the alliance was to stop Soviet expansionism by serving as NATO's southern flank. ${ }^{40}$

With its involvement in the Korean War, Turkey not only became a strategic ally, but also a symbol of how successful US foreign policy could be in 'containing' the Soviets. Turkey's inclusion in NATO was perceived not only in military but also in political and cultural terms as a new role for the country: partner of the West. ${ }^{41}$

\subsection{Turkey and the US in the Middle East}

For George Harris, the Middle East "formed a major testing ground for the Turkish-American alliance in the first decade of Turkey's membership in NATO." ${ }^{42}$ During the Cold War years, the US as a global power had several geopolitical objectives. For example, it aimed to prevent a possible Soviet attack in the region, to secure NATO's southern flank, to support Israel, to maintain western supply lines in the Mediterranean, and to access and control Middle Eastern oil. ${ }^{43}$ Although Turkey's main role in the alliance was to engage the Soviet Union, Ankara also played a major role in the strategy to preserve Western interests in the Middle East. ${ }^{44}$ In fact, Turkey contributed to the stability of the region, which was crucial to US interests and provided an important access point to the Middle East.

At the beginning of the Cold War, the US administration located Turkey by using various geopolitical metaphors such as a natural "barrier" against Soviet expansion, a "deterrent" to a Soviet attack and a "challenge" to the Soviet Union's southern flank. Another geopolitical image, the "Northern Tier" (comprised of Turkey, Greece, and Iran), was also used at this time, during British-American talks on the Middle East held in Washington. Accordingly, it was agreed that the security of the eastern Mediterranean and the Middle East were crucial to both powers, that both must support it and that the independence and territorial integrity of the Northern Tier countries must be maintained. It can be argued here that the term Northern Tier stressed the strategic significance of Turkey in Anglo-American plans for defending the Middle East against an attack from the Soviets on the Suez Canal. ${ }^{45}$

During the 1950s, Turkey proved its geopolitical importance to the US administration and cooperated with other US allies within the Middle East, including Iran, Israel, and Jordan, to contain the influence of Soviet clients such as Egypt, Iraq, and Syria. As evidence of its allegiance, Turkey joined the Baghdad Pact in 1955, allowed the US to use its military bases in Operation Lebanon for extra-NATO purposes after the Iraqi revolution in 1958, allowed Jupiter Missiles to deploy in its territory in 1959, was the first Muslim country to recognize Israel in 1949, and proved to be a significant partner in the US Middle East policy determined by the Eisenhower Doctrine, outlined in March 1957. In 1959, after Iraq withdrew from the Baghdad Pact, it was renamed the Central Treaty Organization (CENTO), and mainly aimed

\footnotetext{
39 NATO, "NATO Enlargement," accessed April 1, 2010, http://www.nato.int/cps/en/natolive/topics_49212.htm.

40 Richard Perle and Michael J. McNamara, "US Security Assistance for Turkey and the Challenge of Aid for the Southern Flank," NATO's Sixteen Nations 32 (1987): 94-97.

41 Bruce Kuniholm, "Turkey and NATO: Past, Present and Future," ORBIS (1983): 422.

42 Harris, "Turkey and the US," 54.

43 Nasuh Uslu, The Turkish-American Relationship between 1947 and 2003: A History of a Distinctive Alliance (New York: Nova Science Publishers Inc., 2003), 104.

44 Ömer Karasapan, "Turkey and US Strategy in the Age of Glasnost," Middle East Report (1989): 7.

45 Bruce Robellet Kuniholm, The Origins of the Cold War in the Near East: Great Power Conflict and Diplomacy in Iran, Turkey, and Greece (Princeton, NJ: Princeton University Press, 1980), 57.
} 
to guarantee US military and financial aid to the region. ${ }^{46}$

As a result of the East-West détente during the 1960s and 1970s, Turkey's geopolitical significance to the US decreased, and relations between the two countries deteriorated. For example, Turkey refused to allow the US to use its military bases to support Israel during the Arab-Israeli Wars of 1967 and 1973. ${ }^{47}$ Similarly, the Bilateral Defense and Cooperation Agreement of 1969 limited US military activities in Turkey. ${ }^{48}$

However, the end of the détente strengthened the Turkish-American alliance in the 1980s, and the reasons for this rapprochement were similar to those in the 1950s: the Soviet threat and Turkey's 'strategic importance.' For US Ambassador George McGhee, “The fluid situation in Afghanistan since the Soviet withdrawal, the withdrawal of Iran from cooperation with the West, and the uncertainty regarding Greek NATO commitment leave Turkey as the only reliable element in the northern tier of the Middle East." ${ }^{49}$

During the 1980s, the Carter Doctrine applied the US containment policy to the Gulf region. On January 23, 1980, President Carter claimed that the US would use military force when necessary to protect its interests (oil) in the Middle East, and thus it attempted to increase its military capabilities in the region. Turkey and the US signed a new Defense and Economic Cooperation Agreement (DECA) on March 29, 1980 (the first was signed in 1969, after the US refused to support Turkey in intervening in the Cyprus crisis). ${ }^{50}$ After Turkey's September 1980 military coup, US military aid increased tremendously and Turkey strengthened its role as a pillar of Washington's strategy to protect American interests in the Middle East. Turkey also received large amounts of economic aid, principally organized by the OECD. ${ }^{51}$

In light of the above synopsis, it can be argued that the Cold War as a geopolitical narrative was created by the superpowers' strategic elites. The Cold War geopolitical discourse consisted of powerful political ideology, representing world politics as a struggle between 'us' and 'them.' Overall, as Ó Tuathail argues, 'the discourse of Cold War geopolitics helped to secure and emphasize a set of geographical identities like 'the West', 'the Soviet Union', 'the United States', while serving to discipline domestic social and cultural differences within these spaces. ${ }^{, 52}$ As argued above, an alliance with Turkey was an important part of US geopolitical discourse in the Cold War. From the Truman Doctrine to the Carter and Reagan doctrines, Turkey was part of every strategic plan developed by Washington in that era. From the time World War II ended, the US aimed to 'contain' the Soviet Union and Turkey perceived Turkey as "the stopper in the neck of the bottle," as quoted above. As a result of this geopolitical significance, which was critical to the containment of Soviet expansion, Turkey and the US became allies and consequently established close military ties.

\section{The Military Dimension of Turkey-US Relations}

Strategic/military relations have always been the vital element in Turkish-American relations.

46 Behçet Kemal Yeşilbursa, The Baghdad Pact: Anglo-American Defense Policies in the Middle East: 1950-1959 (New York: Frank Kaas, 2005), 210.

47 Kuniholm, The Origins of the Cold War in the Near East, 426.

48 Çağrı Erhan, "Türkiye ile ABD Arasında İkili Anlaşmalar," in Türk Dış Politikası, ed. Oran, 556.

49 McGhee, The US-Turkish-NATO-Middle East Connection, 177.

s0 Dankwart A. Rustow, Turkey: America's Forgotten Ally (New York: Council on Foreign Relations, 1987), 104-105.

51 "US Military Aid and Arms Sales to Turkey (see 1980-1992)," Federation of American Scientists, accessed October 17, 2010, http://www.fas.org/asmp/profiles/turkey_fmschart.htm.

52 Gearóid Ó Tuathail, Critical Geopolitics, 42. 
During the Cold War, the US administrations divided the world into 'friendly' and 'hostile' spaces, and military activities and political alliances were justified on the basis of this geographical and ideological division. In this period, the US perceived Turkey as a barrier against the Soviet Union and perhaps more importantly, as a military base in the Middle East and eastern Mediterranean. Thus, supporting and modernizing the Turkish army and establishing military and intelligence facilities in Turkish territory were the major methods by which the US achieved its global aims in the region.

During the Cold War, US security assistance programs were designed by the Truman Administration, which conveyed that military/economic assistance was an important instrument in US post-war policy. ${ }^{53}$ Between 1947 and 1950, Turkey and Greece received $\$ 600$ million in US military and economic aid. Thereafter, Turkey became one of the most important recipients of US grants. The US also gave assistance to Turkey through the Joint United States Military Mission for Aid to Turkey (JUSMMAT). ${ }^{54}$

In official documents, it was argued that US assistance would enable Turkey "to strengthen its security forces and to maintain the stability of her economy." ${ }^{55}$ Continuation of this aid was justified by Turkey's geopolitical importance. In May 1949, the US State Department defended US military aid to Turkey as follows: “Turkey's military strength will make available to the US and to our allies the use of this vitally strategic area as a base of operations in the event of war, and conversely deny the Soviet Union and its satellites access to its land and resources." ${ }^{\circ 6}$

The Turkey-US Military Facilities Agreement in 1954 formalized the opening of US bases on Turkish territory, through which the US administration attempted to defend its global geopolitical interests. Thus, the issue of military bases is accepted as one of the most important aspects of the Turkish-American relationship. However, Turkey used these facilities as a bargaining chip during the détente years, such as when it refused to allow the US to use them to support Israel during the Arab-Israeli Wars. They also became sources of conflict, particularly in the 1970s, when the Turkish administration and the Turkish people wanted all of them closed.

It should be noted that Turkish-American intelligence cooperation against the Soviet Union became crucial during the 1980 s, as Turkey also represented a critical location for intelligence monitoring stations. The collapse of the Iranian regime in 1979 and the ensuing end of the US-Iranian intelligence relationship created a gap in US intelligence coverage of the southern part of the Soviet Union and US military installations close to the oil regions of the Gulf.

The end of the détente and the beginning of the 'second' Cold War between the US and the Soviet Union reinforced the Turkish-American alliance. It is important to note that Turkey's September 1980 military intervention did not negatively affect relations. On the contrary, the US did not criticize the military administration and confirmed that American aid to Turkey would not be interrupted. Indeed, the logic of this support was mirrored in the rhetoric of the Truman era. According to Commander-in-Chief of Allied Forces Southern Europe Admiral

\footnotetext{
53 US Congress House Committee on Foreign Affairs Hearings, Assistance to Greece and Turkey, 80th Cong., 1st sess., 1947, 385-386.

${ }_{54}$ William N. Farmen and Erwin F. Lessel III, "Forward Presence in Turkey: Case Study," Parameters (1992): 19-20.

55 United States, "Agreement Between the United States of America and Turkey Respecting Aid to Turkey," United States Statutes at Large 62 (1948): 2953.

56 US Department of State, Policy Statement (Washington DC, May 5, 1949), 1.
} 
William J. Crowe, "Turkey sits on the flank of any Soviet thrust into Iran or the Persian Gulf and is the only alliance nation which is Muslim and geographically located in the Middle East." He also added that "[n]o Western or Soviet planner can address the Middle East challenge without considering Turkey's orientation, terrain, airspace, forces, and bases." ${ }^{57}$

In this context, Turkey's geopolitical importance significantly increased given the Soviet intervention in Afghanistan, the Islamic Revolution in Iran, and the Iran-Iraq War. ${ }^{58}$ At that time, Turkey began to change its foreign policy by taking into consideration American sensitivities, and consequently withdrew its veto over Greece's entry into the military branch of NATO.

Meanwhile, in accordance with the Carter Doctrine, Defense Secretary Alexander Haig developed the idea of the Rapid Deployment Force to protect the US' "vital interests" in the region. ${ }^{59}$ This task force, which would become the US Central Command (CENTCOM), was to command operations in the Gulf region. ${ }^{60}$ Turkey and the US had a shared policy to support multilateral and bilateral reactionary conduct against the communist bloc, and as a consequence of this policy, Ankara accepted deployment of the task force project.

The 1980 DECA reflected US objectives to maintain a strong Turkish-American bilateral defense relationship and preserve its military facilities in Turkey, ${ }^{61}$ and the Turkish-American Defense Council was established in 1981. On November 29, 1982, a memorandum of understanding was signed and accepted as a supplementary agreement to DECA, which approved upgrading ${ }^{62}$ the three US bases in Turkey (Erzurum, Batman, and Muş). Military aid levels from the US during this period were the highest since the Korean War. Turkey ranked fourth in the number of US nuclear weapons deployed overseas in this era - about 489 in $1985^{63}$ - but economic and military aid from the US began to decrease in 1984.

The Özal government was established after the Turkish general elections in 1983. In 1985, Özal requested a revision of DECA, and on December 18 the agreement was renewed for another five years. However, largely on the basis of US Congress discussions related to the Cyprus and Armenian issues, Turkey did not put the agreement into effect until $1988 .{ }^{64}$

It can be summarized that as a result of the close relationship between the two countries, Turkey provided critical base facilities to the US and the US provided economic and military aid to Turkey. As it can be seen, military relations were the most important aspect of US strategic interests. Strategically, the US perceived Turkey as a base from which to reach Middle Eastern oil and problematic areas near the Soviet Union. At the end of the Cold War, the question of Turkey's strategic importance increased concerns in Turkey and the US, which led to changes in their relationship.

\section{Limits of the Alliance: The Cyprus Problem}

Between 1960 and 1975, the decrease in tension between the US and the Soviet Union, also decreased Turkey's geopolitical significance to the US. Indeed, the golden years of the

\footnotetext{
57 William J. Crowe, Jr, "NATO’s Southern 'Sideshow' due for Center Ring?” Christian Science Monitor, October 22, 1980,
}

58 Albert Wohlstetter, “Meeting the Threat in the Persian Gulf," Survey 25 (1981): 175

59 Ibid., 161-168.

60 İlhan Uzgel, “ABD ve NATO’yla İlişkiler,” in Türk Dış Politikası, ed. Oran, 246.

61 Karasapan, "Turkey and US Strategy in the Age of Glasnost," 9.

62 "United States Treaties and Other International Agreements," US Department of State 35, no.6 (1983-1984): 6063.

${ }_{63}$ Robert Mcdonald, "Alliance Problems in the Eastern Mediterranean -Greece, Turkey and Cyprus: Part II," Adelphi Series 229 (1988), 214 
US-Turkish alliance ended with the Cyprus crisis, which is considered the most important problem between the two countries during the 1960s and the 1970s. Cyprus was perceived as a 'national cause' for Turkey and Greece; because of its geographical proximity to Turkey and considerable Turkish population, Cyprus became a security concern for Turkey in the case of annexation of the island by Greece, and thus became a driving factor in Turkish foreign policy during the Cold War.

For the US administration, Cyprus has been strategically significant because of its geopolitical position at the crossroads of three continents and its geographical position on the major routes between the West and the East; it is also the only island in the southeastern Mediterranean. ${ }^{65}$ Cyprus also controlled the passages of the gas and oil pipelines north of the Suez Canal. For the above reasons, it became a crucial base for operations in those regions.

The main focus of US administrations regarding the Cyprus question was to contain the conflict and to prevent a war between Greece and Turkey, both of whom were strategically important allies of the US. In Monteagle Stearns' analysis, the US needed to address several dangers. First, in the event of war between Turkey and Greece, NATO could be destabilized and weakened, and thus its southeastern flank could collapse. Second, the political, military, and economic cooperation between the US, Greece, and Turkey could be undermined and the presence of American base facilities in these countries could be threatened. Finally, the prestige of the Western alliance could be damaged because such hostility could be considered a symbol of Western disunity. ${ }^{66}$

By the mid-1950s, ethnic conflicts began to increase between the Turkish and Greek populations of Cyprus. Moreover, tension continued to rise between Greece and Turkey until 1959, when both states agreed to form a united Cyprus under one constitution and one flag at the Zurich and London Conferences. The Republic of Cyprus was established in August 1960. ${ }^{67}$ The Treaty of Guarantee, signed by Britain, Turkey, and Greece, was added to the Cypriot constitution. As a result, these three nations became guarantor states of Cyprus' security and independence.

In November 1963, Greek Cypriot President Makarios moved to limit the political rights of the Turkish Cypriot community by way of constitutional amendment. This action led to violence, especially against the Turkish community, ${ }^{68}$ and turned the situation into a crisis.

In June 1964, conditions worsened for Cypriot Turks, and responding to public pressure, the Turkish government decided to intervene militarily under the 1960 Treaty of Guarantee. ${ }^{69}$ When Ankara informed Washington of its intentions, President Lyndon B. Johnson wrote Turkish Prime Minister İsmet İnönü a letter that US Undersecretary of State George Ball called "the most brutal diplomatic note [he had] ever seen."70 Johnson warned İnönü that NATO would not defend Turkey against the Soviet Union if Turkey intervened in Cyprus. He also stated Turkey could not use military equipment supplied by the US if it did choose to intervene. In his response, Prime Minister İnönü stressed that this perceived conditional

65 Jones, The Fifteen Weeks, 58.

66 Monteagle Stearns, Entangled Allies: US Policy Toward Greece, Turkey and Cyprus (New York: Council on Foreign Relations, 1992), 11-16.

67 Theodora Kalaitzaki, “US Mediation in Greek-Turkish Disputes since 1954," Mediterranean Quarterly 16 (2005): 112.

68 Süha Bölükbaşı and White Burkett, The Superpowers and the Third World: Turkish-American Relations and Cyprus (New York: University Press of America, 1988), 55-56.

69 Cihat Göktepe, "The Cyprus Crisis of 1967 and its Effects on Turkey's Foreign Relations," Middle Eastern Studies 41 (2005): 435 .

70 Uslu, The Turkish-American Relationship, 170 
commitment of the NATO alliance would damage its credibility, but in the end the Turkish government withdrew its intention to intervene in the Cyprus conflict. ${ }^{71}$

The Johnson letter had a long-time impact on Turkish-American relations. The letter showed that the US was not willing to trigger the NATO mechanism in support of Turkey, "even though the most vital Turkish interests were at stake." 72 The Turkish government was disappointed that "their most important ally, the United States, not only would not help them in a deeply felt cause, but apparently disagreed profoundly on the force of [the] NATO commitment to defend Turkey." ${ }^{73}$ After the shock of the Johnson letter, the Turkish government decided to limit US military activities on Turkish territory. In July 1969, Turkey and the US signed the first Bilateral Defense Cooperation Agreement, in which the US was made to accept Turkish sovereignty over all installations. ${ }^{74}$

The Cyprus issue returned to the agenda when the ruling military junta in Greece supported a coup attempt against Makarios in July $1974 .{ }^{75}$ Consequently, acting under Article 4 of the Treaty of Guarantee, on July 20, Turkish troops intervened on the island to protect the Turkish community. Although diplomatic efforts were initiated, the Turkish government intervened again, this time on August 14, taking control of approximately 40 percent of the island and with the aim of resolving the security concerns of the Turkish community there. ${ }^{76}$

Perhaps the most difficult period in the Turkish-American relationship followed the Cyprus intervention. In response to this intervention, the US Congress imposed a military embargo against Turkey to force it to withdraw from Cyprus. While the US did not generally consider embargoes as effective tools to achieve its policy objectives in the eastern Mediterranean, Congress insisted on prohibiting arms sales to Turkey. The provisions of Section 620 (X) of the Foreign Assistance Act went into effect on February 5, 1975. As a result, over 200 million USD in arms purchases, grants, and commercial military sales to Turkey were cancelled. ${ }^{77}$

Supporters of the embargo asserted that Turkey illegally used US arms during the Cyprus operation. ${ }^{78}$ Those opposing the embargo, including President Gerald Ford, argued that refusing to help Turkey would damage US efforts in the Cyprus peace negotiations. Ford added that this aid ban would also negatively affect Turkish-American relations and weaken the "crucial position of the United States in the East Mediterranean."

The anti-embargo argument justified its opposition with geopolitical language and made several significant points. First, that it was impossible to solve such a problem using blunt force. Second, that it would damage the US' geopolitical interests in the region; ${ }^{80}$ indeed, the arms embargo did not compel the Turks to cooperate, but instead resulted in loss of US influence over Turkey. Third, that closing US military bases on Turkish territory would put an end to its intelligence facilities, and thus to its monitoring of Soviet military activities. And finally, that the embargo would weaken NATO's southeastern flank. ${ }^{81}$

Cengiz Başak, "The Policies of the Major Powers Towards Cyprus Crisis and United Nations (UN) Operations in Cyprus (UNFICYP) Between the Years of 1964-1974," Foreign Policy 2 (1998): 116.

72 H W. Jr. Brands, “America Enters the Cyprus Tangle 1964,” Middle Eastern Studies 23 (1987): 351.

73 Uslu, The Turkish-American Relationship, 170.

Bölükbaşı and Burkett, The Superpowers and the Third World, 72.

75 Melek Fırat, "Yunanistan'la İlişkiler," in Türk Dış Politikası, ed. Oran, 739.

6 Ellen B. Laipson, Congressional-Executive Relations and the Turkish Arms Embargo (Washington: USGPO, 1981), 1.

77 US House of Representatives and Senate, Legislation on Foreign Relations Through 1979: Current Legislation and Related Executive Orders: vol. 1 (Washington, USGPO, 1980), 113.

78 Nasuh Uslu, Türk-Amerikan İlişkilerinde Kıbrıs (Ankara: 21. Yüzyıl Yayınları, 2000), 325.

79 Ibid., 331.

80 Ibid., 334-335.

81 Laipson, Congressional-Executive Relations and the Turkish Arms Embargo, 26. 
As a first reaction to the embargo, Turkey unilaterally declared the establishment of the Turkish Federated State of Cyprus on February 13, 1975. Prime Minister Bülent Ecevit also overturned the prohibition on opium production. Next, on June 17, the Turkish administration announced that all US military and intelligence facilities in Turkey would be placed on "provisional status." ${ }^{2}$ On July 26, Turkey cancelled the 1969 DECA and closed all US military facilities in Turkey except NATO bases. ${ }^{83}$

Jimmy Carter was elected president of the US in 1976. He argued that the uneasy relations with Turkey produced important problems for the Western defense system, and the embargo was lifted in October 1978. It is important to emphasize that this decision was made just as the US was about to lose Iran as an ally. ${ }^{84}$ On October 3, 1978, although the US and Turkey still did not agree over DECA, Turkey agreed to re-open its US military bases. ${ }^{85}$

The 1974 Cyprus crisis marked a new era in American-Turkish relations. With the impact of the détente between the two blocs and the strong anti-American feeling in Turkey, Turkey wanted to reduce its dependency on the US and improve its relations with the Soviet Union. ${ }^{86}$ The embargo most certainly damaged Turkey's economy and defense capacity and created doubts about the reliability of the US. It also weakened NATO's southern flank, negatively affecting US security interests. And finally, the embargo failed to help resolve the Cyprus issue. Since the end of World War II, US administrations had assumed they had Turkey's unconditional support regarding US geopolitical interests in the region, regardless of Turkey's domestic interests. However, on the Cyprus issue, US policies failed primarily because they used Turkey to realize their objectives in the region at the expense of Turkish national interests; many in the US administration also failed to understand that Cyprus was more important to both Turkey and Greece than NATO was. ${ }^{87}$

During the Cyprus crises, Turkey also learned several lessons about its alliance with the US. The Cyprus intervention highlighted the importance of public opinion in Turkey's foreign policy, even when it was shaped primarily by external factors, and even in light of US opposition. The Cyprus issue heralded an era in which domestic concerns took on a more prominent position in shaping Turkish foreign policy. ${ }^{88}$ It became clear that Turkey's unconditional loyalty to the West could be costly to its own security. NATO support was conditional and political, and Turkey learned it could not necessarily rely on NATO in a time of crisis. ${ }^{89}$

Critical geopolitics stresses the importance of geopolitical language in foreign policymaking. Geopolitical discourses shape minds and justify policy actions. TurkishAmerican relations during the Cold War were shaped by US administrations' geopolitical concerns, such as preventing the expansion of communism, and Turkey largely adapted itself to this discourse. However, the Cyprus issue and its related developments, such as the Johnson letter and the arms embargo, created deep mistrust and suspicion between the US and Turkey. These crises revealed the limits of US geopolitical discourse in Turkish-American relations.

82 Laurence Stern, The Wrong Horse: The Politics of Intervention and the Failure of the American Diplomacy (New York: Times Books, 1977), 155.

83 Laipson, Congressional-Executive Relations and the Turkish Arms Embargo, 25

84 Theodore A. Couloumbis, The United States, Greece and Turkey: The Troubled Triangle (New York: Praeger, 1983$), 106$.

85 Stern, The Wrong Horse, 155.

86 Sedat Laçiner, “Turkish Foreign Policy (1971-1980): Ideologies vs. Realities," Uluslararası Hukuk ve Politika 6 (2010): 91.

87 Kalaitzaki, "US Mediation," 109

88 William Hale, Turkish Foreign Policy 1774-2000 (London: Frank Caas, 2000), 159.

89 Kalaitzaki, "US Mediation," 111. 


\section{Conclusions}

This article argues that 'geopolitical imaginations' are closely linked to practice, in that they are used to justify states' decisions. Indeed, the geopolitical narrative of the Cold War created a world in which two superpowers tried to establish their own spheres of influence.

After World War II, Turkey, with its proximity to the Soviet Union, found itself in a geography in which the two superpowers strategized about how to dominate the oil-rich Middle East. Soviet territorial demands on Turkey in 1939 caught the attention of the US administration and obliged Washington to cooperate with Turkey to prevent Soviet expansionism. It can be argued that the Turkish-American relationship during the Cold War was a product of these deeply ideological conditions.

Turkey's primary value in the eyes of US during the Cold War was its geographical location; the country was seen as a buffer between the Soviet Union and the Middle East. Turkey became a part of the US containment policy with the Truman Doctrine and received a huge amount of military and economic aid through the Marshall Plan. President Truman used the falling-dominoes metaphor with respect to Turkey and Greece to justify US military actions in the region. As a part of the containment policy, numerous military bases and US facilities were opened on Turkish territory, which have been central to understanding the strategic nature of the alliance during and after the Cold War. In Cold War language, Turkey was regarded as a barrier, a military base, and/or a NATO ally, whose purpose was to contain and prevent Soviet expansionism, especially in the Middle East.

Turkey's participation in the Korean War and its inclusion in NATO showed that security and geopolitics were key terms in US state discourse regarding Turkey. Accordingly, during this period, Turkey was accepted as a Western ally and as part of the 'West.' It was the end of the Cold War and the collapse of the Soviet Union that eradicated the East-West division and challenged Turkey's position in the West. ${ }^{90}$

The Cyprus issue was the most important conflict of the Turkey-US relationship. Turkey perceived this issue as a national cause because it felt that ethnic conflicts would threaten the existence of the Turkish community on the island. Despite vigorous opposition by the US, the Turkish military intervened Cyprus on July 20, 1974 in accordance with the rights given by Article 4 of the Guarantor Agreement. The Cyprus crisis revealed the costs associated with being so dependent on the US, and forced Turkey to reduce this dependence. For its part, the US realized that it had not taken into account the strength of Turkey's national feeling, and that Turkey's domestic interests ultimately took precedence over a US alliance.

After the Cold War, new geopolitical imaginations and practices changed the significance of Turkey's geography for the US. That redefinition has mostly been accepted but occasionally resisted by subsequent Turkish administrations. It is important to analyze this new geopolitical understanding in light of current world events, but those are saved for a future study.

\section{Bibliography}

“Boğazlar Konusunda Amerika'nın Türkiye’ye 2 Kasım Notası.” In Belgelerle Türk-Amerikan Münasebetleri edited by Fahir Armaoğlu. Ankara: Türk Tarih Kurumu Basımevi, 1991.

"Position on Question of the Turkish Straits-Exchange of Notes Between the Soviet Chargé d'affaires and Acting Secretary Acheson.” Department of State Bulletin 374, September 1, 1946.

90 P1nar Tank, "Dressing for the Occasion: Reconstructing Turkey's Identity," Southeast European and Black Sea Studies 6 (2006): 463 
“Statement by Acting Secretary Acheson.” Department of State Bulletin 409-A, May 4, 1947.

Altunışı, Meliha, and Özlem Tür. Turkey: Challenges of Continuity and Change. New York: Routledge Curson, 2005.

Başak, Cengiz. "The Policies of the Major Powers Towards Cyprus Crisis and United Nations (UN) Operations in Cyprus (UNFICYP) Between the Years of 1964-1974.” Foreign Policy 2 (1998): 27-42.

Bilsel, Cemil. "The Turkish Straits in the Light of Recent Turkish-Soviet Russian Correspondence." The American Journal of International Law 41 (1947): 727-747.

Brands, H W., Jr. “America Enters the Cyprus Tangle 1964.” Middle Eastern Studies 23 (1987): 348-367.

Bölükbaş1, Süha, and White Burkett. The Superpowers and the Third World: Turkish-American Relations and Cyprus, New York: University Press of America, 1988.

Cohen, Sam. "US Bases in Turkey to Reopen.” Christian Science Monitor, October 6, 1978.

Couloumbis, Theodore A. The United States, Greece and Turkey: The Troubled Triangle. New York: Praeger, 1983.

Crowe, Jr, William J. “NATO’s Southern ‘Sideshow' due for Center Ring?” Christian Science Monitor, October 22, 1980.

Dobson, Alan P., and Steve Marsh. US Foreign Policy since 1945. New York: Routlegde, 2001.

Donovan, Robert J. Conflict and Crisis: The Presidency of Harry S Truman, 1945-48. New York: Norton \& Company, 1977.

Erhan, Çağrı. “Türkiye ile ABD Arasında İkili Anlaşmalar.” In Türk Dış Politikası: Kurtuluş Savaşından Bugüne Olgular, Belgeler, Yorumlar, Cilt 1: 1919-1980, edited by Baskın Oran, Ankara: İletişim, 2001.

Farmen, William N., and Erwin F. Lessel III, “Forward Presence in Turkey: Case Study.” Parameters (1992): 19-28.

Federation of American Scientists. "US Military Aid and Arms Sales to Turkey (see 1980-1992)." Accessed October 17, 2010. http://www.fas.org/asmp/profiles/turkey_fmschart.htm.

Fırat, Melek. "Yunanistan'la İlişkiler.” In Türk Dış Politikası: Kurtuluş Savaşından Bugüne Olgular, Belgeler, Yorumlar, Cilt 1: 1919-1980, edited by Baskın Oran, , Ankara: İletişim, 2001.

Göktepe, Cihat. "The Cyprus Crisis of 1967 and its Effects on Turkey's Foreign Relations.” Middle Eastern Studies 41 (2005): 431-444

Gönlübol, Mehmet. "NATO and Turkey, An Overall Appraisal." The Turkish Yearbook Of International Relations 11 (1971): 1-38.

Gürün, Kamuran. Türk-Sovyet İlişkileri: 1920-1953. Ankara: Türk Tarih Kurumu Basımevi, 1991.

Hale, William. Turkish Foreign Policy 1774-2000. London: Frank Caas, 2000.

Harris, George S. Troubled Alliance; Turkish-American Problems in Historical Perspective, 1945-1971. Washington: American Enterprise Institute for Public Policy Research, 1972.

Howard, Harry. "Some Recent Developments in the Problem of the Turkish Straits, 1945-1946." Department of State Bulletin 395 (January 26, 1947).

Jones, Joseph M. The Fifteen Weeks: February 11-June 5, 1947. New York: The Viking Press, 1955.

Kalaitzaki, Theodora. "US Mediation in Greek-Turkish Disputes since 1954.” Mediterranean Quarterly 16 (2005): 106-124.

Karasapan, Ömer. "Turkey and US Strategy in the Age of Glasnost.” Middle East Report 160 (1989): 4-10.

Kuniholm, Bruce. "Turkey and NATO: Past, Present and Future." ORBIS (1983): 421-445.

Kuniholm, Bruce. The Origins of the Cold War in the Near East: Great Power Conflict and Diplomacy in Iran, Turkey, and Greece. Princeton, NJ: Princeton University Press, 1980.

Laçiner, Sedat. “Turkish Foreign Policy (1971-1980): Ideologies vs. Realities." Uluslararası Hukuk ve Politika 6 (2010): 61-100.

Laipson, Ellen B. Congressional-Executive Relations and the Turkish Arms Embargo. Washington: USGPO, 1981.

Leffler, Melvyn P. "Negotiating from Strength: Acheson, the Russians, and American Power." In Dean Acheson and the Making of U.S. Foreign Policy, edited by Douglas Brinkley, London: Macmillan, 1993.

Leffler, Melvyn P. "Strategy, Diplomacy, and the Cold War: The United States, Turkey, and NATO, 1945-1952." The Journal of American History 71 (1985): 807-825.

Mcdonald, Robert.“Alliance Problems in the Eastern Mediterranean -Greece, Turkey and Cyprus: Part II.” Adelphi Series 229 (1988).

McGhee, George. The US-Turkish-NATO Middle East Connection: How the Truman Doctrine and Turkey's NATO 
Entry Contained the Soviets. Houndmills, Basingstoke, Hampshire: Macmillan, 1990.

NATO. "Final Communiqué." Accessed April 1, 2010. http://www.nato.int/docu/comm/49-95/c510920a.htm.

NATO. “NATO Enlargement.” Accessed April 1, 2010. http://www.nato.int/cps/en/natolive/topics_49212.htm.

Nixon, Richard. “Address to the Nation on the War in Vietnam.” Accessed March 13, 2010. http://www.presidency. ucsb.edu/ws/?pid=2303

Ó Tuathail, Gearóid, and John Agnew, eds. A Companion to Political Geography. Washington: Blackwell, 1998.

Ó Tuathail Gearóid, and John Agnew, "Geopolitics and Discourse: Practical Geopolitical Reasoning in American Foreign Policy.” Political Geography 11 (1992): 190-204.

Oran, Baskın. ed. Türk Dış Politikası: Kurtuluş Savaşından Bugüne Olgular, Belgeler, Yorumlar, Cilt 1: 1919-1980. Ankara: İletişim, 2001.

Perle, Richard, and Michael J. McNamara, "US Security Assistance for Turkey and the Challenge of Aid for the Southern Flank." NATO's Sixteen Nations 32 (1987): 94-97.

Rustow, Dankwart A. Turkey: America's Forgotten Ally, New York: Council on Foreign Relations, 1987.

Stearns, Monteagle. Entangled Allies: US Policy Toward Greece, Turkey and Cyprus. New York: Council on Foreign Relations, 1992.

Stern, Laurence. The Wrong Horse: The Politics of Intervention and the Failure of the American Diplomacy, New York: Times Books, 1977.

Tank, Pinar. "Dressing for the Occasion: Reconstructing Turkey's Identity." Southeast European and Black Sea Studies 6 (2006): 463-478.

Truman, Harry. "The Truman Doctrine, Public Papers of the Presidents of the United States." In The Geopolitics Reader, edited by Gearóid Ó Tuathail et.al. London: Routledge, 1998.

United States. "Agreement Between the United States of America and Turkey Respecting Aid to Turkey." United States Statutes at Large 62 (1948).

US Congress House Committee on Foreign Affairs Hearings. Assistance to Greece and Turkey 80th Cong., 1st sess., 1947.

US Department of State. FRUS: National Security Affairs; Foreign Economic Policy, 1950, vol. I. Washington, D.C.: USPGO, 1950.

US Department of State. FRUS: Eastern Europe: the Soviet Union, vol. VI. Washington, D.C.: USGPO, 1946.

US Department of State. FRUS: The Near East and Africa, 1946 vol. VII. Washington, D.C.: USGPO, 1946.

US Department of State. FRUS: The Near East, South Asia, and Africa, 1949, vol. VI. Washington, DC: USGPO, 1949.

US Department of State. United States Treaties and Other International Agreements, vol. 35, no. 6. Washington, DC: USGPO, 1983-1984.

US Department of State. Policy Statement. Washington, DC: May 5, 1949.

US Department of State. Department of State Bulletin 16 (January-March 1947).

US House of Representatives and Senate, Legislation on Foreign Relations Through 1979: Current Legislation and Related Executive Orders: vol. 1. Washington, USGPO, 1980.

Uslu, Nasuh. The Turkish-American Relationship between 1947 and 2003: A History of a Distinctive Alliance. New York: Nova Science Publishers Inc., 2003.

Uslu, Nasuh. Türk-Amerikan İlişkilerinde Kıbrıs. Ankara: 21. Yüzyıl Yayınları, 2000.

Uzgel, İlhan. “ABD ve NATO’yla İlişkiler.” In Türk Dış Politikası: Kurtuluş Savaşından Bugüne Olgular, Belgeler, Yorumlar, Cilt 1: 1919-1980, edited by Baskın Oran, Ankara: İletişim, 2001.

Ülman, Haluk. Türk-Amerikan Diplomatik Münasebetleri: 1939-1947. Ankara: Sevinç, 1961.

Wilson, Edwin C. Istanbul Press Reactions March 14 to Truman Speech. Ankara, March 14, 1947.

Wohlstetter, Albert. "Meeting the Threat in the Persian Gulf." Survey 25 (1981): 128-188.

Yeşilbursa, Behçet Kemal. The Baghdad Pact: Anglo-American Defense Policies in the Middle East: 1950-1959. New York: Frank Kaas, 2005.

Y1lmaz, Şühnaz. "Challenging the Stereotypes: Turkish-American Relations in the Inter-War Era," Middle Eastern Studies 42 (2006): 223-237. 